\title{
Some remarks on stress and reduction correlations in Spanish
}

Key w ord s: consonant weakening; Spanish stress; vowel reduction; speech perception; perception cues

Słow a klucze : redukcja samogłosek; redukcja spółgłosek; akcent hiszpański; percepcja mowy; rytm

\section{Introduction}

Given the abundance of vowel reduction phenomena spreading across the different language families, phonetic and phonological reduction is usually analysed with respect to vocalic segments. It is, however, also the domain of consonants. Certain languages, such as Spanish, tend to preserve their vowels - both in quantitative and qualitative terms - regardless of the speech rate, and reduce the articulatory features of the consonants. Most Spanish dialects are very much advanced in weakening phenomena, such as debuccalization and assimilation of preconsonantal codas, spirantization of intervocalic stops and word-final or intervocalic deletions, pointing very clearly to the universal lenition pattern (Harris 1969; Lipski 1996). These processes can be gradual and very often depend on social factors, producing variation in the speech patterns of different, or even the same speakers, which makes it difficult to 
analyse them on purely phonological grounds or establish the phonemic status of such changes. Closely related languages, on the other hand (e.g. Portuguese or Catalan), seem to present different patterns, with significant reductions in vowels (Mateus, Andrade 2002; Mascaró 1978) ${ }^{1}$. Why is it that Spanish seems to resist one type of reduction while engaging in another with such mastery? This paper aims at addressing this issue, suggesting that a language's stress pattern is strictly connected with the freedom of reduction. A disruption of this pattern may inhibit comprehension and speech perceptibility, vowels being the principal stress and melody carriers. Syllable timing makes Spanish quite different from languages with rhythmic and phrasal stress patterns, such as French or English in which the role of vowels in carrying overall rhythm and melody, and hence crucial prosodic information, is limited to full/stressed vocalic segments. Restricted or inexistent vowel reduction levels in syllable-timed languages, on the other hand, are less costly in the process of communication due to more regular syllable duration distribution.

Nevertheless, the supposed inexistence of vowel reduction in Spanish may be countered by certain dialectal properties, such as Mexican or Andean vowel reduction (Lope Blanch 1972, Lipski 1990). Interestingly, these varieties have a tendency to preserve their consonants rather than weaken them, which points to an interesting correlation between the two types of reduction processes. Furthermore, even languages traditionally perceived as non-reducing (e.g. Polish, Nowak 2006) have been reported to show schwa-

${ }^{1}$ It is generally assumed that Romance languages are syllable-timed. Nevertheless, there are exceptions, e.g. French has phrasal stress and vowel reduction, and such languages as Catalan or Portuguese are difficult to classify. They combine the properties of Spanish and English in some respects and do present vowel reduction. They can be therefore considered mixed systems - a conclusion which is still subject to debate (see Nespor 1990, but also Prieto et al. 2012). What is interesting is that mixed or stress-timed systems tend to have different stress cues and more robust vowel inventories as opposed to 'classical' syllable-timed languages. According to Prieto et al., both phonological and phonetic factors come into play here, and despite some similarities between systems, durational vs. spectral differences between vowels in reduction contexts determine the rhythm of a given language, which obscures the traditional division: syllable-timed vs. stress-timed. Under an approach admitting more factors, Catalan is closer to Spanish (syllable-timed rather than stress-timed like English). In this paper, I use the traditional classification as Spanish is undoubtedly syllable-timed and duration differences between its vowels are very small across contexts. 
like sounds in certain positions in rapid speech, which can be attributed to Lindblom's (1963) phonetic undershoot discussed in the following sections. In the following parts of is paper, I present a general phonological and phonetic background of the discussed phenomena and examine the nature of reduction, its dependence on stress and implications for language acquisition, perception and typology. This is effected based on the example of Spanish. Based on evidence from this language, I assume that vocalic stability facilitates consonant weakening while vocalic instability blocks it, hence the two types of reduction are correlated to some extent and result from languagespecific restrictions concerning sound distribution. At the same time, speech comprehension is facilitated by language-specific perceptual cues resulting from the sound inventory. In the case of Spanish, duration and intensity are the most important perceptual cues and their disruption inhibits lexical access. Thus, the presence or absence of certain types of phonological processes is of consequence for the phonology-semantics interface. In the following sections, I discuss types of reduction and studies on the perception and production of vowel categories, especially vowel quality, duration and stress that lend support to the hypothesis that extended vowel and consonant reductions are mutually exclusive, and that syllable-based rhythm and small vowel inventories lead to the development of different perceptual cues than stressbased, robust systems.

The paper is structured as follows. Section 2 presents an overview of reduction processes in Spanish; section 3 discusses types of vowel reduction, section 4 analyses the implications of reduction and stress for perception and production. Section 5 summarises the theoretical discussion and provides general conclusions.

\section{Reduction processes in Spanish}

This section presents an overview of cross-dialectal instantiations of reduction in Spanish, with a special focus on the Spanish consonants. As is well-known, and fruit of numerous studies on the various lenition phenomena in the language (Brown 2009; Bybee 2002; Fontanella de Weinberg 1973; Lipski 1996; Terrell 1979), virtually (and fruit of numerous studies on the various reduction/lenition phenomena in the language, e.g. Brown 2009; Bybee 2002; Fontanella de Weinberg 1973; Terrell 1979; see Lipski 1996 for an over- 
view), virtually all dialects of Spanish present some degree of reduction in consonantal features. One of the most studied processes of this type is spirantisation. According to this rule, intervocalic stops across the Spanish-speaking world (with a possible exception in certain Central American varieties, Joan Mascaró, p.c.) become something between fricatives and weak approximants in connected speech, both inside words and across word boundaries. Thus [b d g] become [ $\beta$ ð y], e.g. lobo [lo. $\beta \mathrm{o}]$ 'wolf', dedo [de.ðo] 'finger', trigo [tri.yo] 'wheat'. Given the fact that the process extends to all but prenasal and absolute-initial positions and can be advanced up to the point of total segment loss (e.g. hemos hablado [e.mo.sa.bla.ðo] > [e.mo.sa.ßla.o] 'we have talked'), it is best analysed as an instance of feature reduction and, generally, consonant weakening.

Among other processes of reduction in the sense of weakening and (gradual) loss of consonantal features, Spanish exhibits word-final consonant weakening that includes devoicing, spirantization and elision as particular strategies: Madrid rendered [ma.ðrit] / [ma.ðrï] / [ma.ðri]. Meanwhile, the renowned coda $s$ aspiration (i.e. debuccalisation to [h]) involves the loss of place features in various environments ranging from preconsonantal, through prepausal to prevocalic. Yet again, the process of aspiration is further expanded to gemination, preaspiration and consonant elision. Thus, depending on the dialect meses 'months' can surface as [me.seh] or [me.se], while puesto 'post' as [pweh.to], [pwe ${ }^{\text {h }}$ to], [pwet.to] or [pwe.to]. Similarly, the phrase chicas guapas 'pretty girls' has either [t]i.kah.ywa.pah] or [t]i.ka.ywa.pa] as its surface representation, while the phrase chicas altas 'tall girls' exhibiting prevocalic and prepausal $s$ has at least 3 possible renderings: [t fi.ka.sal.tah], [t fi.ka.hal. tah] or [t]i.ka.hal.ta] (Kenstowicz 1996; Broś 2012, 2015). Last but not least, the Caribbean jota weakening can be added as another consonantal reduction process in Spanish. By this rule, the velar fricative debuccalises to glottal [h], as in elige 'choose' (imperative) [e.li.he], estar juntos 'to be together' [eh.tar. hun.toh] (Lipski 1996; Quesada Pacheco 2010). The Spanish-speaking world is currently divided into varieties that present only the glottal variant, dialects that have both the velar fricative and the glottal one (the latter as a result of $s$ aspiration) and dialects with the velar fricative only (not to forget Peninsular Spanish which has a uvular voiceless fricative inexistent elsewhere).

This overview is certainly not exhaustive, but definitely provides a general idea of the extent to which Spanish reduces consonants. The question 
is what happens with the Spanish vowel inventory. As stated in the introduction, unlike some related languages Spanish seems to have a particularly conservative vowel system in which only 5 vowels exist and remain stable in both synchronic and diachronic terms ${ }^{2}$. According to Sessarego (2012), the language does not have a particularly 'crowded' vowel space. It is a syllabletimed language in which all vowels have more or less the same length if we ignore anatomical and general phonetic principles whereby e.g. open vowels are inherently longer than close vowels. Besides, these scarce vocalic segments present very limited variability across contexts. There is no significant difference in length between stressed and unstressed vowels in Spanish and, all of the above facts combined, it is reasonable to assume that reducing vowels might disrupt the Spanish stress pattern in three crucial areas: comprehension, speech perceptibility and intonation.

It must also be pointed out that much of morphological and grammatical information is stress-bound in this language. There are numerous minimal pairs differing in stress that distinguish between the present and the past tense, indicative and subjunctive modes, verbs and conjunctions/relative pronouns, etc. Some examples are listed below.

(1) Stress-bound grammatical differences in Spanish te 'you', clitic vs. té 'tea' cantara 'I/(s)he sing' past subj. vs. cantará '(s)he will sing' hablo 'I speak' $\quad$ vs. habló '(s)he spoke' hable '(s)he speak' subj. Vs. hablé 'I spoke'

Against this background, it is particularly interesting to learn that some Spanish dialects do present some degree of vowel reduction (VR henceforth) according to linguists. These include some parts of Mexico, Peru and other Andean regions. Curiously, the same varieties tend to have no accompanying consonant weakening. Although these cases need further investigation, substantial descriptive literature can be found as support of the above claim.

The first dialect exhibiting some vowel reduction is the Spanish of Central Mexico studied by Lope Blanch (1972) based on the speech of 100 in-

${ }^{2}$ I ignore historical processes involving diphthong formation etc. in the evolution of Spanish from Latin. 
formants from Mexico City. According to this study, vowel reduction encompasses a series of changes ranging from partial devoicing to complete elision, passing through a number of intermediate stages (1972: 57-58). According to Lope Blanch and Boyd-Bowman (1952), the most important factor affecting vowel reduction is the surrounding consonantal environment, especially voiceless [s]. Thus, VR involves predominantly $e$ in $s$ contexts and is not accompanied by consonantal reduction. According to several sources, this Spanish variety has a strong sibilant $/ \mathrm{s} /$ with no reduction, a strong $/ \mathrm{j} /$, often realised as a fricative ([j], whereas it tends to be reduced to a glide in other dialects, also within Mexico) and a strong velar fricative sound. By contrast, the Spanish of Yucatán has a weak / $\mathrm{j} /$ that is often elided, /s/ that is sometimes aspirated or deleted, as well as instances of $/ \mathrm{x} /$ weakening to $/ \mathrm{h} /$. What is more, stressed vowels are lengthened in this dialect and no VR can be observed (Alvar 1969; Lope Blanch 1972; Boyd-Bowman 1952; Lipski 1996).

High rates of VR have been reported for the highlands of Ecuador (including Quito). The changes range from devoicing to elision, predominantly in mid vowels in contact with /s/. The percentages of vowel deletion according to vowel position in the word are as follows: $/ \mathrm{i} / 50 \%$, /e/ $30 \%, / \mathrm{u} / 5 \%$, and negligible rates for $/ \mathrm{a} / \mathrm{and} / \mathrm{o} / \mathrm{in}$ a non-final syllable; /e/ 75\%, /o/ 10\% and /a/ 4\%, and negligible rates for $/ \mathrm{i} /$ and $/ \mathrm{u} /$ in the final syllable (Lipski 1990: 13). Lipski also indicates that vowel reduction in the final syllable has higher rates due to the status of /e/ as the default vowel, as well as to the predictability of /o/ in the plural of verbs (e.g. nosotros bailamos 'we dance'). Other features of this dialect include the fact that the coda /s/ remains a sibilant and can undergo voicing before a vowel, as in los amigos [lo.za.mi.yos] 'friends'. It is important to note, however, that the latter process is more frequent without VR (Lipski 1996, Robinson 1979). What is more, the dialect has a clear distinction between the palato-alveolar fricative and the palatal approximant (a consonantal feature considered very conservative and called lleísmo). Ecuadorian Spanish also presents fortition rather than lenition in consonants in the affrication of the /tr/ sequence.

Cusco Spanish is yet another variety where VR has been detected so far (Lipski 1990, Hundley 1983, Delforge 2006, 2008). According to Delforge (2008), Cusco Spanish VR rates are: /e/ 20\%, /o/ 13\%, /i/ 13\%, /a/ 8\%, and /u/ $5 \%$. Adjacent voiceless segments favour vowel reduction. This is because of the late-occurring glottal opening gestures, for instance in fricatives, which 
makes these sounds more likely to overlap the gesture of the following segment. Thus, VR is an instance of devoicing by gestural overlap more than anything else and occurs in [p_s], [s_s] and [m_s] contexts. Among other features characterising this variety of Spanish, it should be mentioned that there is a general tendency to reduce the vocalic system from 5 to 3 vowels due to contact with Quechua (a 3-vowel system) that generates confusion in the distinction between high and mid vowels in many bilingual speakers, not only in Peru, but also in Bolivia and other Andean areas (Lipski 1996). As far as consonantal phenomena are concerned, there is a clear distinction between the lateral palatal and the central palatal sound (lleismo) and a strong unreduced /s/ sometimes produced as an interdental. What is more, voiced interdentals are retained and often strengthened to plosives.

In Bolivia, the Afro-Yungueño dialect was first studied by Gordon (1980) and based mostly on impressionistic observations. According to this scholar, vowel weakening most frequently affects unstressed /e/, followed by /o/, /a/ and /i/, especially in the / $\mathrm{tVs} /$ environment. VR ranges from partial to complete devoicing to elision, but the rates of reduction are quite low and highly dependent on morphological conditioning and frequency effects (Lipski 2007, Sessarego 2012). Sessarego reports, specifically, following others, that mid vowels are more affected in final than in non-final syllables, while the opposite applies to high vowels (which are infrequent in word-final position). Vowel /a/ is almost never reduced. Interestingly, VR also applies in voiced contexts, usually after $/ \mathrm{m} /$ in the final syllable of the plural in verbs. Complex noun phrases in plural, where both the final /s/ and the vowel are predictable, is the usual environment of VR: dos chicos peruanos 'two Peruvian guys'. All in all, Sessarego indicates a lower rate of reduction in unstressed vowels in Bolivia than in Cusco (Delforge's data), but both results are negligible: $3.5 \%$ for Bolivian and $9.9 \%$ for Cusco. Other features of Highland Bolivian Spanish include: strong unreduced /s/, no spirantisation of intervocalic stops in some speakers, strengthening: affrication of /tr/, strong velar/palatal fricative, and a tendency to reduce the vocalic system from 5 to 3 (Lipski 1996).

Before moving on to the discussion of vowel reduction in general, it is worth summarising the VR findings for Spanish. It seems that the phenomenon is not too extended and presents both inter- and intraspeaker variation (Lope Blanch 1972, Gordon 1980) plus very low rates of occurrence, suggest- 
ing that it is merely a coarticulatory effect. ${ }^{3}$ The contexts of its occurrence do not seem to be particularly uniform: although it is largely vowels that stand next to voiceless segments that are affected, some reports also include postnasal contexts. The neighbourhood of $/ \mathrm{s} /$, however, seems to be prevalent ${ }^{4}$. This is also in line with the fact that the process appears to be morphologically and grammatically dependent (plural of nouns and adjectives, plural verb conjugations), and requires some level of sound/meaning predictability. The mid vowel /e/, often reported to be the default vowel in Spanish, is the most frequently affected, especially in post-tonic (and word-final) position. The position in a word is a simple indicator of the advancement of reduction. For instance, in Cusco word-initial devoicing is rare, pretonic non-initial is slightly more frequent, while word-final syllables exhibit most frequent and most extended (strongest) devoicing. Most 'apparently elided' items were reported there ( $87 \%$ of complete devoicing and apparent deletion in word-final prepausal contexts, Delforge 2008: 115). This points to the pathway of information salience: the amount of information that can be inferred based on the previous part of the speech signal increases in a linear fashion, i.e. the beginning of the word will not be comprehensible if substantially reduced, which makes it a prominent position, often subject to fortition. The end of a word is more predictable as it is the host of grammatical category markers rather than lexical meaning 5 .

Most importantly as to the phonological consequences of VR in Spanish, neither devoicing (partial vowel reduction) nor elision triggers weakening or assimilatory processes in coda consonants (Lipski 1990). The latter process is especially controversial. Given the fact that many of the studies

${ }^{3}$ Lope Blanch and Gordon report variable reduction in about half of their speakers. Delforge (2008) divides her speakers into 'frequent' and 'infrequent' vowel-reducers. In her study on Cusco Spanish, "[o]f a total of 16,581 unstressed vowels in the sample, $1,648(9.9 \%)$ were identified as reduced".

${ }^{4}$ Lope Blanch reports that $90 \%$ of the reductions appear next to /s/, while Delforge's study mentions $69 \%$. Interestingly, $83 \%$ of the devoicing in the latter study occurs between two voiceless consonants, and a further $14 \%$ between a consonant and a pause.

5 This, combined with the morphological conditioning mentioned above, makes a good argument for positing a lexical diffusionist trajectory of language change for these varieties of Spanish - from frequent words and based on lexical/grammatical predictability rather than spontaneous phonetic change. The opposite view is not totally contrary to this conclusion. In fact, the two explanations can be combined, as explained by Labov (1994, see also Broś 2015). 
on VR in Spanish are largely impressionistic, it cannot be straightforwardly determined whether elision actually takes place or is a merely perceptual effect, especially that it is found in predictable, word-final environments and does not affect the neighbouring sounds that would otherwise undergo phonological processes. The authors themselves do not agree on the matter. Lope Blanch, for instance, is skeptical, claiming that it is difficult to determine whether elision takes place by ear. Canellada and Zamora Vicente (1960) note novel consonant clusters as a result of deletion, while Lipski argues that the elided segments must be somehow retained in the underlying structure for the purposes of phonology. The nature of reduction is also debatable: most Spanish sources use the word relajación 'relaxation', which is imprecise, to say the least. More recent studies provide a clearer phonetic description of the observed changes based on acoustic data. Thus, Delforge deems vowels to be partially devoiced when the length of their voice bar is $30 \mathrm{~ms}$ or less. When there is no glottal tone, but some energy is observed on the spectrogram in F1 and F2, the vowels are considered fully devoiced. With no formants and no voice, the vowel is analysed as 'apparently elided'. Because Delforge's study does not provide information on the movement of the articulators, it cannot be ultimately determined whether such extremely reduced vowels are actually deleted (i.e. lack corresponding gestures). As the comparison of the formant values between the stressed and unstressed tokens did not confirm any significant differences, it seems reasonable to conclude that VR in Cusco concerns voicing only, and not any vowel quality features (Delforge 2008: 112).

It must be emphasised that, as mentioned above, various factors have been provided as contributors in the process of Spanish VR. Apart from the vicinity of voiceless segments (Boyd-Bowman 1952; Lope Blanch 1972), morphological predictability (Lipski 1990), post-tonic position (Canellada, Zamora Vicente 1960; Matluck 1952) and vowel quality (chiefly mid vowels ${ }^{6}$, e.g. Lipski), speech rate ${ }^{7}$, word frequency (Delforge 2008; Lipski 1990, 1996) and position in the intonational phrase (Delforge 2008) can be added to the list. VR

${ }^{6}$ Which is in line with prominence and contrast discussed in the next section, but against the insight that high vowels are most likely to be coarticulatorily devoiced due to their inherent short duration and limited sonority.

7 Although not all researchers agree. According to Delforge (2008), contrary to expectations, speech rate does not seem to be that relevant for Cusco Spanish due to the fact that reduction was observed even in very slow speech. 
is therefore a highly variable process of a phonetic nature. It is also one that occurs in the absence of consonantal weakening in a given dialect. And, most interestingly, it does not involve the 'usual' weakening processes of vowelreducing languages, such as raising or centralisation. It is most of all related to a different set of features responsible for devoicing best described in terms of Browman \& Goldstein's (1990) gestural coordination and overlap ${ }^{8}$. Crucially, the process does not affect the quality of the Spanish vowels, although it does affect durational distances between the different types of syllables: pretonic, tonic, post-tonic, prepausal, and can exert influence on the overall stress pattern of Spanish in the regions under discussion. Given the lack of studies on this particular issue, such a line of reasoning cannot be pursued here. I will assume, however, that the presence of VR (although purely phonetic and non-contrastive as far as the reported data are concerned) and the lack of simultaneous consonantal reduction stand in some sort of relationship. In other words, such 'alternating' reductions are not accidental. In the meantime, the vast majority of Spanish dialects that do not exhibit vowel reduction of any kind strongly rely on the rigid vowel system and on the stress and intonation that go with it. Before discussing the implications of these facts, let us go through the different types and classifications of vowel reduction, as well as through the consequences of VR for sound perception and production.

\section{Types of vowel reduction}

There has been a long debate concerning various types of vowel reduction and their consequences for phonology. Some reductions can be classified as purely phonetic, without consequence for the phonological processes or the inventory of the vowel phonemes. These reductions are highly variable and context-dependent. Categorical vowel reduction, on the other hand, introduces contrast and tends to influence a given language's phonology in various other ways.

Another classification worth considering when studying cross-linguistic patterns and contrasts is the division between prominence-reducing VR in

8 Although, according to Delforge, most devoicing occurs between voiceless consonants, devoicing rates are highest for /i/ and / $\mathrm{u} /$, and some 'departures' from crosslinguistic trends can be observed, such as the frequent devoicing of /e/ word-medially (2008: 122). 
which a "change in vowel quality leads to a decrease in articulation time" (Crosswhite 2001) and rate-induced vowel undershoot that consists in the "displacement of a given vowel in the direction of the surrounding consonantal environment" (Lindblom 1963) and is a result of the "pressure to avoid effortful articulations" (Crosswhite 2001). The first type is centralising, involves the distinction between corner and non-corner vowels, and stands opposite to contrast enhancement expressed e.g. by means of tensing (or raising). The second type of VR is more in line with devoicing cases observed across languages, and especially in Spanish - the topic of this paper.

The different classifications of VR result from the fact that the underlying cause of reduction is still under debate. This is strictly related to the very definition of vowel reduction. According to Lindblom (1963), VR is a gradual process that results in a shrunken vowel space. This being rather uncontroversial, the question is whether vowel reduction in unstressed positions is due to shorter duration, more marked coarticulation or reducing articulatory effort, or maybe a combination of the three factors (Mooshammer, Geng 2008). The processes that can be classified as belonging to the VR category have been studied under several types of conditions so far, not only unstressed position, but also different speech tempos, variability in connected speech, differences across the different prosodic constituents and boundaries, across different lexical / grammatical categories, etc. (e.g. Lindblom 1963). Across all these conditions VR is usually observed together with the change in vowel duration, suggesting a clear correlation in this dimension. Thus, it may be concluded that whenever vowel duration decreases, reduction occurs, at least to some degree. This situation was dubbed target undershoot by Lindblom (1963) and further expanded by e.g. Flemming (1995, 2004). In line with the gestural timing observations within the framework of articulatory phonetics and phonology (Browman, Goldstein 1989, 1990), the less time the articulators have to move from one configuration to another, the more coarticulatory effects will be observed and the less precise they will be in reaching their target at any given time. This, in turn, will be reflected in vowel formant changes and the apparent shrinking of the vowel space - all vowels will be less 'precise' and less perfect formant-wise.

The notion of prominence is central to the study of VR (Crosswhite 2001, Harrington et al. 2000). Stressed vowels need to be more prominent: more audible, precise and peripheral to ensure contrast. This can be viewed in terms 
of enhancement, or lack of it in the case of the less prominent unstressed vowels. In non-prominent positions vowels tend to be shorter, less precise in articulation and less peripheral, hence centralised. They are also more prone to coarticulation with the neighbouring sounds, especially when found between consonants. Nevertheless, in most languages in which VR in unstressed syllables leads to the neutralisation of vowel contrasts (purportedly via target undershoot and gradual phonetic changes, as argued e.g. by Flemming 1995, 2004) height is the most affected dimension. The changes start with shrinking the vertical space by raising low vowels, while front-back changes are much more restricted (Crosswhite 2001, 2004).

Crosswhite (2004) analyses VR as driven by two separate mechanisms: prominence and contrast. Thus, prominent segments should be avoided in non-prominent positions (low, sonorous vowels such as /a/ should be raised/ reduced). At the same time, however, contrast should be enhanced and noncorner vowels should be avoided in unstressed positions due to the difficulty in maintaining contrasts in reduced, shorter segments. This favours /a/ and disfavours mid and centralised vowels. Crosswhite further divides reductions themselves into contrast-enhancing and prominence-reducing types. The former ensures that "certain undesirable or perceptually-challenging vowel qualities are limited to stressed position" (2004: 3), thus non-corner vowels are given up. The end result is a limited vowel inventory for non-prominent positions, one that offers maximal dispersion / distinctiveness (Lindblom 1986). The second type of VR is very well-attested and presents raising and reduction to schwa. It is driven by the desire to avoid saliency in non-prominent positions, and both high vowels and centralised vowels are in line with this criterion, high vowels being fairly constricted and the shortest due to minimal jaw opening and schwa being the most neutral spacewise ${ }^{9}$.

Note that the area of interest in Crosswhite's analyses is VR seen as contrast neutralisation and therefore a phenomenon of consequence to the phonology. No such effect has been reported in Spanish or similar languages, apart from the fact that the type of reduction seems to be completely different. Even though the effect of the neighbouring sounds was mentioned in all of the studies, supporting the correlation between duration and undershoot and, consequently, coarticulatory effects - the outcome was invariably vow-

9 Crosswhite (2004: 30) mentions Bulgarian and Sri Lankan Portuguese as examples. 
el devoicing and not changes in quality or aperture that might be interpreted anywhere near the reductions of Lindblom $(1963,1986)$, Flemming (2004) or Crosswhite (2004). It is true, however, that extreme cases of devoicing lead to elision - a possible end result in typical vowel reduction languages (e.g. English or French). Indeed, Crosswhite (2004) argues that the restriction on noncorner vowels in non-prominent positions seems to hold only in languages in which stress is correlated with increased duration. No such effects are valid in intensity-based stress languages (e.g. Czech) or those that use pitch accent. ${ }^{10}$ This would include the syllable-timed Spanish.

\section{Stress, vowel reduction and perception/production}

The principal assumptions of this paper follow from the discussion of vowel reduction and the consonant/vowel reduction discrepancy discussed so far. As already mentioned, my hypothesis is that since the stress pattern is somehow connected with the freedom of reduction, stress and reduction are correlated, and therefore the change or even minor disruption of a language's stress pattern may inhibit comprehension and speech perceptibility. Stress and VR-related comprehension problems may point to some cues to stress and reduction perception, and to the nature of the supposed sensitivity to stress shift, and vowel duration and quality changes in the speakers of a syllable-timed language. Thus, auditory perception requires closer attention in the context of both stress shift and VR.

Speech perception goes back yet again to ideas concerning dispersion and enhancement in sound inventories. Naturally, apart from the fact that each language is governed by similar principles (or rather tendencies, e.g. for the front vowels to be unrounded and back vowels to be rounded, for the maximization of contrast/perceptual distance between the existing sounds etc.), those languages that have developed more robust vowel inventories will accept smaller increments in perceptual saliency, and therefore smaller

10 Spanish uses pitch accent in prominent syllables in intonational contours. The pitch accent is independent of lexical stress and can have different values (rising, falling, flat) depending on the position of a word in the sentence and type of utterance (e.g. statement vs. question). Interestingly, Navarro Tomás (1964) calls stress an 'intensity accent' to differentiate it from intonational stress (pitch accent). In this paper, I refer to pitch accent when talking about intonation. For a phonetic study on stress and accent in Spanish, see e.g. Ortega-Llebaria (2006). 
differences will be perceived and distinguished from the rest by their speakers. Languages with basic 5-vowel systems (e.g. Spanish), on the other hand, have more perceptual space between each of the vocoids at their disposal and will therefore be guided by other cues than speakers of 12-vowel systems (e.g. English).

Vowel contrasts are typically described as governed by a set of acoustic parameters, chiefly the first and second formant (Liljencrants, Lindblom 1972). "Maximally distinct contrasts are preferred because they are less likely to be confused by listeners" (Flemming 2005: 3). Thus, maximising distinctiveness is a key perceptual principle. This can be 'facilitated' by enhancement, i.e. the presence of additional features that enhance the effect of distinctive features pertaining to a given sound and help the listener better identify the sound and contrast it with other sounds in the inventory (Diehl 1991; Ohala 1985; Stevens, Keyser, Kawasaki 1986). Such contrasts can be neutralised in non-prominent positions, allowing for less distinct but more context-dependent vowel qualities (e.g. F2 contrasts are neutralised in vertical vowel inventories and centralising reduction languages such as English, in which all vowel qualities can be reduced to schwa - a sound that is highly influenced by the surrounding sounds). From the point of view of the differences between the vowel inventories of different languages and the consequent discrepancies in their stress patterns (rhythmic, stress-timed, syllable-timed etc.), it would be interesting to test the perception and production of non-native patterns and see how they relate to the general observations on contrast and perceptual considerations in phonemic inventories.

Studies involving second language acquisition (SLA) may shed some light on the predictions concerning the above. Gómez Lacabex, García Lecumberri \& Cooke (2007), for instance, tested the perception of English vowel reduction by trained Spanish learners. They follow the insight of previous studies in SLA in assuming that non-native contrasts are difficult to both perceive and produce due to the native inventory bias. Unknown and untrained contrasts are difficult to perceive for speakers whose inventories are substantially different, although some studies suggest that they can be acquired with sufficient training (e.g. Flege 1995). While schwa is a very frequent reduced variant in English, Spanish lacks centralised vowels of any kind and although it may reduce the duration and movement of the articulators to some degree in rapid speech, the five canonical vowels never lose their quality (Quilis 1996). 
According to some previous studies on these issues, Spanish speakers tend to be heavily influenced by spelling ( $<\mathrm{a}>$ is always [a], whether it is the word 'and', 'an' or 'sand') ${ }^{11}$ and while some awareness of the schwa can be observed, major problems are encountered in production (Kondo 1995). Most importantly, however, vowel reduction and stress seem to be independent of one another for these speakers (Flege, Bohn 1989). Meanwhile, the perception of schwa by untrained speakers of Spanish is a mere $62 \%$, not too much above the chance performance levels for perception tasks based on minimal pairs (Gómez Lacabex, García Lecumberri 2005). Moreover, students are more likely to (erroneously) perceive reduction in strong words than in weak words, and in word minimal pairs rather than syllable minimal pairs. This suggests that Spanish speakers largely fail to recognise VR - they cannot reliably discriminate between weak and strong vowels. Specific training is needed, as it was reported to definitely boost both perception and production. ${ }^{12}$ In another study on the perception of vowel reduction by Spanish speakers Diettes (2010) concludes that the subjects (Colombian speakers of Spanish) do not perceive the English schwa as a separate category. Instead, they both perceive and produce it as any of the native vowels depending on the context, and many times relying on spelling.

The results reported above are not contrary to the expectations concerning speakers of a language that presents no sensitivity to stress/lack of stress in terms of vowel quality. What remains to be established is what constitutes the principal cue to stress perception in this language. Some studies have aimed to provide an answer. Cues to lexical stress in Spanish were first discussed in Contreras (1964) and Navarro (1964). According to Navarro, variations in pitch can be associated with intonation, while duration and intensity are the domain of general lexical stress, with an emphasis on the intensity dimension. This is supported by the fact that, as already mentioned, many lexical items in Spanish tend to differ solely in stress and no other phonetic property. Navarro Tomás cites such triplets as límite-limite-limité 'limit' (noun), 'limit' $\left(1^{\text {st }} / 3^{\text {rd }}\right.$ p. sg. present subjunctive), 'limited' ( $1^{\text {st }}$ p. sg. past tense), célebre-celebre-celebré 'famous', 'celebrate' ( $1^{\text {st }} / 3^{\text {rd }} \mathrm{p}$. sg. present subjunctive), 'celebrated' or

11 The example comes from my own experience in teaching English pronunciation to foreign students. The same conclusions are drawn by Diettes (2010).

${ }^{12}$ Lively et al. (1994), McClasky et al. (1993), Flege (1988), Gómez Lacabex, García Lecumberri, Cooke (2007). 
depósito-deposito-depositó 'deposit/warehouse', 'deposit' ( $1^{\text {st }}$ p. sg. present indicative), 'deposited'. Spanish contains innumerable examples of this kind. According to Navarro, the only phonetic difference between these variants lies in intensity, thus it may be concluded that 'the Spanish ear is especially sensitive to this cue' (1914: 177).

The greatest difficulty in studying stress cues lies in the fact that Spanish stressed syllables tend to coincide with pitch accents responsible for intonation. It may be that pitch and duration are therefore cues to accent (intonation) rather than (lexical) stress. To disentangle the two domains and their corresponding cues, Ortega-Llebaria (2006) analysed pitch, duration and intensity in accented stressed syllables, unaccented stressed syllables and unstressed syllables in native Spanish speakers and then compared utterances with an intervening intonational phrase boundary with those without it. The study revealed that the IP boundary was a determining factor in the patterning of pitch and duration, but not intensity. Duration is apparently sensitive to all phonological categories, accented stressed syllables being the longest, followed by unaccented stressed and unstressed syllables. Only accent seems to be correlated with pitch changes (F0). Unaccented vowels, even when stressed, did not present pitch changes. Further evidence for the discrepancy between stress and accent cues is provided by Ortega-Llebaria \& Prieto (2007) who examine the stress contrast between accented and deaccented syllables. Crucially, intensity was found to be a determining factor for stress in terms of perception. Stressed syllables are possibly perceived as more prominent in Spanish "due to an increase in the intensity levels in the higher [...] regions of the spectrum", a phenomenon referred to as spectral tilt (2007: 19). Duration, however, was also reported to be of importance as a cue in this study. Another cue: vowel quality was observed in the case of mid vowels. Slight centering movements could be distinguished in acoustic terms in unstressed positions.

While vowel reduction is an important cue for stress in some languages (e.g. English, Huss 1977; Beckman \& Edwards 1994), ${ }^{13}$ other languages present a strong preference for other cues, such as duration and intensity, despite having centralised vowels (e.g. Dutch, Sluijter, van Heuven 1996; Sluijter, van

13 According to Huss' study, English speakers cannot distinguish between stressed and unstressed syllables solely by duration and intensity cues in the absence of pitch differences and/or vowel reduction. 
Heuven, Pacilly 1997) ${ }^{14}$. Meanwhile, according to a perception study conducted on Catalan speakers, duration and intensity cues play a role in the perception of vowel [i] that does not undergo reduction in unstressed syllables, while vowel quality was the dominant cue for the reducing [a], which is similar to the results for English (Ortega-Llebaria, Prieto \& Vanrell 2008). ${ }^{15}$ In other words, despite the correlation between vowel quality and stress, reduction is not equivalent to the absence of stress. Speakers depend on a cluster of cues in order to perceive stress depending on the stress/accent context, and on the vowel. Spanish, on the other hand, in the absence of vowel reduction and when pitch differences are disregarded, shows that the perception of stress is highly vowel-dependent. While low vowel [a] is perceived largely based on duration, this cue has hardly any effect on the perception of [i] in the case of which intensity is the decisive factor. Production experiments show larger duration differences for more open vowels ([o] against [i] in Llebaria's studies), which, combined with the perception data, can be attributed to the inherent properties of vocoids, at least to some extent..$^{16}$ Nonetheless, the result certainly informs us on the correlation between at least these two cues. Most importantly, it should be noted that in the absence of vowel quality changes and pitch fluctuations, Spanish speakers are able to correctly identify stress in minimal pairs, relying on both duration and overall intensity. Naturally, due to the lack of VR in Spanish, vowel reduction is not a possible cue for stress recognition. All in all, duration seems to be a stronger cue than intensity across all contexts in both production and perception, which is in line with other studies on the perception of stress (e.g. Turk, Sawusch 1996).

Concluding the discussion on stress perception, it may be said that Spanish native speakers should be rather apt at identifying stress and stress contrasts due to the fact that Spanish uses contrastive stress and endows its speakers

14 The difference between Dutch and English may be attributed to the fact that although both languages have vowel reduction, unlike in English where most unstressed vowels are reduced regardless of morphology, in Dutch reduced vowels are usually found in affixes (Gussenhoven 2003).

${ }^{15}$ Catalan is like Dutch and English in that it presents vowel reduction. In Central Catalan, the vowel inventory is reduced to $[\mathrm{i}, \mathrm{u}]$ and schwa in unstressed syllables.

16 A generalisation has to be drawn based on incomplete data given the fact that the production study mentions a discrepancy between the mid rounded vowel and [i] only, while the perception study focuses on the contrast between [a] and [i], disregarding other vowels. 
with a couple of 'detection mechanisms': cues based on greater relative duration and intensity of the stressed vowels as opposed to unstressed ones regardless of vowel quality. ${ }^{17}$ When it comes to the detection of other vocalic features pertaining to the stress pattern realm, such as stress-induced vowel reduction, Spanish speakers are expected to fail given the absence of vowel quality changes and therefore VR as a cue to stress recognition in their own language. As demonstrated by perception experiments conducted by Broś (2016), this is indeed the case. Whereas stress is identified correctly in nonce words, changes in the original stress of native words disrupt comprehension and Spanish speakers are unable to retrieve words with a shift of the stressed syllable. Centralisation of unstressed vowels poses a serious threat to understanding the speech signal: the reduced vowel, when shortened and changed in terms of quality towards the centre of the vowel space, is either unidentified or recategorised as /e/ or /a/. This result should be interpreted in terms of the robustness of the perceptual space available for speakers of languages with smaller inventories referred to in Section 4.

\section{Summary and general conclusions}

This paper has taken several observations concerning the behaviour of Spanish dialects as a point of departure to the study of correlations between stress and reduction. Given the fact that Spanish has a limited set of more or less evenly distributed vowels that do not change their quality to any substantial degree regardless of stress considerations, as well as the fact that numerous consonantal reductions can be observed instead, it is suggested that one type of reductions excludes the other. Furthermore, an overview of Spanish varieties that have been reported to present vowel reduction demonstrates that in such a case the consonantal inventory seems to be stable, contrary to the lenition patterns observed in the rest of the Spanish-speaking world. This lends support to the idea that vocalic stability facilitates consonant weaken-

17 Spanish speakers may be contrasted with e.g. French speakers who have been deemed 'deaf' to stress contrast by Dupoux et al. (1997). An experimental study conducted by Torreira, Simonet and Hualde (2014) points to the fact that the two cues are not that robust in production and a $37 \%$ error rate in perception is significant, thus context is needed to distinguish between minimal pairs of words with final and penultimate stress. 
ing while vocalic instability blocks it. Regardless of the causative agent, vocalic and consonantal stability seem to be inversely correlated.

Because the Spanish stress pattern is based on duration and intensity rather than other factors in determining which syllables are more prominent, it is further assumed that these cues will be the deciding factors in choosing the stressed syllable in a word and retrieving this word from the lexicon. Reversing the pattern or shifting these correlates of stress to a different position inhibits comprehension or results in confusion when the context cannot help the speaker determine which lexical item is pronounced. This is confirmed by SLA studies and perception experiments discussed herein. Thus, I conclude that Spanish speakers have an internalised mechanism for identifying stress, but also heavily rely on duration and intensity when determining which vowel is stressed. At the same time, because other variables, such as vowel quality, are not used as cues to stress, speakers cannot successfully rely upon them and are confused when confronted with vowel quality changes instead of other correlates. Foreign categories, whenever recognised, have to be accommodated within the native inventory and the choice of a particular vowel quality can be driven by phonetic similarity, spelling or immediate phonetic context.

Thus, in a language where vowels are stable as opposed to consonants, a disruption of this stability inhibits comprehension. There seems to exist a limit as to the number of feature/category/formant changes across the consonant-vowel inventory for communication to proceed uninterrupted. This is best illustrated by the reverse reduction patterns in some of the Spanish dialects and constitutes an important insight into the correlates of stress and vowel perception, as well as possible obstacles as to the acquisition of a second language, especially one that presents different stress/rhythm categorization and cuing. Although further research is needed to confirm the hypothesized correlation between the two types of reduction and its implications for (second) language acquisition, given the general behaviour of natural languages, and articulatory and acoustic minima necessary to foster interspeaker communication, the hypothesis put forward in this paper seems to be wellfounded and worth testing in future investigations. 


\section{Bibliography}

Alvar M., 1969, Nuevas notas sobre el español de Yucatán, Iberoromania 1, p. 159-189.

Beckman M., Edwards J., 1994, Articulatory evidence for differentiating stress categories, In: P. A. Keating (ed.), Papers in laboratory phonology III, Cambridge: CUP, p. 7-33.

Boyd-Bowman P., 1952, La pérdida de vocales átonas en la altiplanicie mexicana, Nueva Revista de Filología Hispánica 6, p. 138-40.

Broś K., 2012, Chilean Spanish s-weakening as an example of phonological opacity, In: J. Błaszczak, B. Rozwadowska, W. Witkowski (eds.), Generative Linguistics in Wrocław No. 2, Wrocław, Poland: University of Wrocław, p. 192-209.

Broś K., 2015, Survival of the Fittest: English and Spanish Fricative Lenition from the Perspective of optimality Theory, Cambridge: Cambridge Scholars Publishing.

BRoś K., 2016, Percepción de acento y acortamiento vocálico en español, Itinerarios 22, p. 13-34.

Browman C., Goldstein L., 1989, Articulatory Gestures as Phonological Units, Phonology 6, p. 201-52.

Browman C., Goldstein L., 1990, Gestural Specification Using Dynamically-Defined Articulatory Structures, Journal of Phonetics 18, p. 299-320.

Brown E.K., 2009, A usage-based account of syllable- and word-final /s/ reduction in four dialects of Spanish, Munich: Lincom Europa.

Bybee J., 2002, Word frequency and context of use in the lexical diffusion of phonetically conditioned sound change, Language Variation and Change 14, p. 261-290.

Canellada M.J.,Zamora Vicente A., 1960, Vocales caducas en el español mexicano, Nueva Revista de Filología Hispánica 14, p. 222-241.

Contreras H., 1964, ¿Tiene el español un acento de intensidad?, Boletín del Instituto de Filología de la Universidad de Chile 16, p. 237-239.

Crosswhite K., 2001, Vowel Reduction in Optimality Theory, New York: Routledge.

Crosswhite K., 2004, Vowel reduction, In: Hayes, B., R. Kirchner and D. Steriade (eds.) Phonetically based phonology, Cambridge: CUP, p. 191-231.

Delforge A.M., 2006, Sociolinguistic Correlates and Phonetic Characteristics of Unstressed Vowel Reduction in Cusco, Peru, Paper presented at NWAV36.

Delforge A.M., 2008, Unstressed Vowel Reduction in Andean Spanish, In L. Colantoni, J. Steele (eds.) Selected Proceedings of the $3^{\text {rd }}$ Conference on Laboratory Approaches to Spanish Phonology, Somerville, MA: Cascadilla Proceedings Project, p. 107-124. 
DiEHL R.L., 1991, The role of phonetics in the study of language, Phonetica 48, p. $120-134$.

Diettes K., 2010, Perception and production of the vowel schwa /a/ by Colombian Spanish speakers of L2 English, MA Dissertation: University of Leeds.

Dupoux E., Pallier C., Sebastián-Gallés N., Mehler J., 1997, A destressing 'deafness' in French?, Journal of Memory and Language 36, p. 406-421.

FLEGE J.E., 1988, Using visual information to train foreign-language vowel production, Language Learning 38(3), p. 364-407.

FLEGE J.E., 1995, Second language speech learning: Theory, findings, and problems, In: W. Strange (ed.) Speech perception and linguistic experience: Issues in cross-language research. Timonium, MD: York Press, p. 233-277.

FleGE J.E., BoHn O.S., 1989, An instrumental study of vowel reduction and stress placement in Spanish-accented English, Studies in Second Language Acquisition 11, p. $35-62$.

Flemming E., 1995, Auditory Representations in Phonology, PhD dissertation, UCLA.

Flemming E., 2004, Contrast and perceptual distinctiveness, In: B. Hayes, R. Kirchner, D. Steriade (eds.), Phonetically based phonology, Cambridge: CUP, p. 232-276 .

Flemming E., 2005, Speech perception in phonology, In: D.B. Pisoni, R.E. Remez (eds.), The handbook of speech perception, Malden, MA \& Oxford: Blackwell, p. 156-182.

Fontanella De Weinberg M.B., 1973, Comportamiento ante -s de hablantes femeninos y masculinos del español bonaerense, Thesaurus 25, p. 12-22.

Gómez Lacabex E., García Lecumberri M.L., 2005, English vowel reduction by untrained Spanish learners: Perception and production, Paper presented at PTLC 2005, London.

Gómez Lacabex E., García Lecumberri M.L., Cooke M.P., 2007, Perception of English vowel reduction by trained Spanish learners, New Sounds 2007: Proceedings of the Fifth International Symposium on the Acquisition of Second Language Speech in Florianópolis, Brasil, p. 293-299.

Gordon A., 1980, Notas sobre la fonética del castellano en Bolivia, In: A. Gordon, E. Rugg (eds.), Actas del sexto congreso internacional e hispanistas, Toronto: Department of Spanish and Portuguese, University of Toronto, p. 349-352.

Gussenhoven C., 2003, Vowel duration, syllable quantity and stress in Dutch, In: K. Hanson, S. Inkelas (eds.), The nature of the word: Essays in honor of Paul Kiparsky, Cambridge, MA: MIT Press, p. 181-198.

Harrington J., Fletcher J., Beckman M., 2000, Manner and place conflicts in the articulation of accent in Australian English, In: M. Broe, J. Pierrehumbert (eds.), Papers in Laboratory Phonology $V$ : Acquisition and the lexicon, Cambridge: CUP, p. 40-51. 
Harris J.W., 1969, Spanish Phonology, Cambridge, Mass.: MIT Press.

Hundley J., 1983, Linguistic variation in Peruvian Spanish: Unstressed vowel and $/ s /$, PhD dissertation, University of Minnesota.

Huss V., 1977, English word stress in post-nuclear position, Phonetica 35, p. 86-105.

Kenstowicz M., 1996, Base-identity and uniform exponence: alternatives to cyclicity, In J. Durand, B. Laks (eds), Current Trends in Phonology: Models and Methods, European Studies Research Institute and University of Salford, p. 363-393.

Kondo Y., 1994, Targetless schwa: Is that how we get the impression of stress timing in English?, Proceedings of the Edinburgh Department Conference '94, p. 63-76.

LABOv W., 1994, Principles of Linguistic Change. Volume 1: Internal Factors, Oxford: Basil Blackwell.

LilJenCRANTS J., LindBlom B., 1972, Numerical simulation of vowel quality systems: The role of perceptual contrast, Language 48, p. 839-862.

LindBlom B., 1963, Spectrographic Study of Vowel Reduction, Journal of the Acoustical Society of America 35, p. 1773-1781.

LindBlom B., 1986, Phonetic universals in vowel systems, In: J.J. Ohala, J.J. Jaeger (eds.), Experimental phonology, p. 13-44. Orlando: Academic Press.

LIPSKi J., 1990, Aspects of Ecuadorian Vowel Reduction, Hispanic Linguistics 4(1), p. $1-19$.

LiPSKi J., 1996, El español de América, Madrid: Cátedra.

LIPSKi J., 2007, Afro-Yungueño speech: The long-lost Black Spanish? Spanish in context 4, p. 1-43.

Lively S., Pisoni D.B., Yamada R.A., Tohkura Y.I., Yamada T., 1994, Training Japanese listeners to identify English /r/ and /1/: III. Long-term retention of new phonetic categories, Journal of the Acoustical Society of America 96(4), p. 2076-2087.

Lope BlAnch J. M., 1972, En torno a las vocales caedizas del español mexicano, Estudios sobre el español de México, Editorial Universidad Nacional Autónoma de México, p. 53-73.

Mascaró J., 1978, Catalan phonology and the phonological cycle, PhD Thesis, MIT.

Mateus M.H., D’Andrade E., 2000, The Phonology of Portuguese, Oxford: OUP.

MatLuCK J., 1952, La pronunciación del español en el valle de México, Nueva Revista de Filología Hispánica 2, p. 109-120.

McClasky C. L., Pisoni D., Carrell T. D., 1983, Transfer of training of a new linguistic contrast in voicing, Perception and Psycholinguistics 34(4), p. 323-330.

Mooshammer C., Geng C., 2008, Acoustic and articulatory manifestations of vowel reduction in German, Journal of the International Phonetic Association 38(2), p. 117-136.

Navarro Tomás T., 1964, La medida de la intensidad, Boletín del Instituto de Filología de la Universidad de Chile 16, p. 231-235. 
NeSPOR M., 1990, On the rhythm parameter in phonology, In: I.M. Roca (ed.), Logical issues in language acquisition, Dordrecht: Foris, p. 157-175.

NowaK P., 2006, Vowel reduction in Polish, PhD dissertation, University of California.

Ohala J.J., 1985, Phonetic Linguistics: Essays in Honor of Peter Ladefoged, New York: Academic Press, p. 223-242.

Ortega-Llebaria M., 2006, Phonetic Cues to Stress and Accent in Spanish, In: M. Diaz-Campos (ed.), Selected Proceedings of the $2^{\text {nd }}$ Conference on Laboratory Approaches to Spanish Phonetics and Phonology, Somerville, MA: Cascadilla, p. 104-118.

Ortega-Llebaria M., Prieto P., 2007, Disentangling stress from accent in Spanish: Production patterns of the stress contrast in de-accented syllables, In: P. Prieto, J. Mascaró, M.-J. Solé (eds.), Segmental and prosodic issues in Romance Phonology, CILT, Amsterdam: John Benjamins, p. 155-176.

Ortega-Llebaria, M., Prieto, P., Vanrell, M. M., 2008, Perceptual evidence for direct acoustic correlates of stress in Spanish, In: J. Trouvain, W. J. Barry (eds.), Proceedings of the 16th International Congress of Phonetic Sciences, Saarbrücken, Germany, 6-10 August 2007, p. 1121-1124.

Ortega-Llebaria P., Vanrell M., 2008, Perception of stress is flexible: Catalan listeners' use of vowel reduction, duration, and intensity cues, Paper presented at the Workshop on Information Structure and Prosody, Studiecentrum Soeterbeeck, Netherlands.

Prieto, P., Vanrell, M., Astruc, L., Payne, E., Post, B., 2012, Phonotactic and phrasal properties of speech rhythm. Evidence from Catalan, English and Spanish, Speech Communication 54, p. 681-702.

Quesada PaCheco M.Á. (ed.), 2010, El español hablado en América Central: nivel fonético, Madrid: Iberoamericana.

Quilis A. 1996, Tratado de fonética y fonología españolas, Madrid: Gredos.

Robinson K.L., 1979, On the voicing of intervocalic s in the Ecuadorian highlands, Romance Philology 33 (1), p. 137-143.

Sessarego S., 2012, Vowel weakening in Afro-Yungueño: Linguistic and social considerations, PAPIA 22(2), p. 279-294.

Sluijter A., van Heuven V., 1996, Spectral tilt as an acoustic correlate of linguistic stress, Journal of the Acoustical Society of America 100(4), p. 2471-2485.

Sluijter A., van Heuven V., Pacilly J., 1997, Spectral balance as a cue in the perception of linguistic stress, Journal of the Acoustical Society of America 101(1), p. 503-513.

Stevens K., Keyser S., Kawasaki H., 1986, Toward a phonetic and phonological theory of redundant features, In: Joseph S. Perkell and Dennis H. Klatt (eds.), Invariance and Variability in Speech Processes, Hillsdale: Lawrence Erlbaum, p. 426-449. 
Terrell T., 1979, Final /s/ in Cuban Spanish, Hispania 62, p. 599-612.

Torreira F., Simonet M., Hualde J., 2014, Quasi-neutralization of stress contrasts in Spanish, In: N. Campbell, D. Gibbon, D. Hirst (eds.), Proceedings of Speech Prosody 2014, Dublin: Trinity College Dublin, p. 197-201.

TuRK A., SAwUSCH J., 1996, The processing of duration and intensity cues to prominence, Journal of the Acoustical society of America 99(6), p. 3782-3790.

\section{Kilka uwag na temat korelacji między akcentem a redukcją głosek w języku hiszpańskim}

(streszczenie)

Jak powszechnie wiadomo, w języku hiszpańskim występuje wiele procesów redukcji spółgłosek. Jednocześnie, system samogłoskowy tego języka jest dość prosty. Obejmuje on 5 stabilnych, równomiernie rozłożonych fonemów, których realizacje są niezmienne bez względu na akcent wyrazowy czy intonację. Na uwagę zasługuje natomiast fakt, że w niektórych dialektach języka hiszpańskiego zaobserwować można redukcję samogłosek w postaci ubezdźwięcznienia, ale bez jednoczesnego występowania zmian spółgłoskowych o charakterze lenicyjnym. Biorąc pod uwagę taką a nie inną dystrybucję procesów redukcyjnych, można dojść do wniosku, że redukcja spółgłosek wyklucza redukcję samogłosek i odwrotnie. Pomiędzy omawianymi dwoma typami zjawisk zachodzi zatem ciekawa zależność, którą warto zbadać pod względem produkcyjnym, percepcyjnym, akwizycyjnym i typologicznym. Szereg badań z zakresu percepcji i produkcji samogłosek przez użytkowników rodzimych języka hiszpańskiego wskazuje na to, że systemy o mało rozbudowanym inwentarzu samogłosek i rytmie sylabicznym polegają na innych sygnałach niż typologicznie inne języki przy rozpoznawaniu akcentu i melodii (jakości samogłoski). Nawet niewielkie zmiany jakościowe i akcentowe wpływają zaś negatywnie na zrozumienie poszczególnych elementów leksykalnych i znacznie zaburzają procesy przetwarzania mowy. 